\title{
I Introduction: treaties in international relations
}

\section{A THE LAW}

\section{Treaties as the Oldest Source of 'International Law'}

It has been claimed quite often that customary international law, that is, unwritten rules based on practice and done in the belief in their righteousness or lawfulness, is the oldest source of international law. In other words, that customary law pre-existed treaties. ${ }^{1}$ Logical analysis may seem to suggest the same temporal priority: a treaty can seemingly be adopted under the law only if there are some common rules on the meeting of wills, on the binding nature of the compact, and so on. ${ }^{2}$ However, historical analysis tends to show that treaties between relatively independent political collectivities preceded customary rules. In order to create common customary rules an 'international society' must have developed and some minimum sense of commonalities between the constituent collectivities must have crystallized. This was not the case in the most remote times, when each society was closed to the outside and rather bellicose in its outlook. The first limited contacts between peoples bear the hallmark of scattered agreements, such as armistices, exchange of prisoner agreements, particular alliances, and so on. Treaty law seems at the root of incipient international society. ${ }^{3}$

1 See for example, L. Oppenheim (ed. by R. Y. Jennings and A. Watts), International Law, Vol. I (9th edn, London, 1992), pp. 25, 31; C. Iannacone, Le fonti del diritto internazionale, Portomaggiore (1925), p. 82.

2 Hence the conclusion of some modern authors that treaties are rooted in customary law and constitute a sort of secondary law, while custom contains the primary rules of international society. See for example, G. Morelli, Nozioni di diritto internazionale (7th edn, Padova, 1967), p. 32.

3 A simple mental experiment may confirm what has been said in the preceding lines. If we assume that some aliens come to Earth, and that it is necessary to set down with them some understandings on a 'law of war' to be applied between us and them, or some form of reciprocal cooperation, it stands 


\section{Legal Conception of Old Treaties}

The foregoing explanations have as a logical corollary that agreements between relatively independent public collectivities are initially not rooted in a common legal order (public international law), superior to the contracting parties and providing for rules such as pacta sunt servanda. Initially, treaties are unilateral acts assumed by each contracting party under its own municipal legal order. To be more precise: by promise, oath to its own Deities and curse clauses. ${ }^{4}$ The binding force of the treaty stems from the fact that it has been sworn to the gods. The gods are expected to guarantee the treaty and to punish any breach of the compact. This conception had some legal consequences. For example, the unilateral nature of treaty conclusion implied that in the case of sequential conclusion, which was the common practice, the party not having already bound itself by the oath could retract from its obligations, while the other party, having already sworn the treaty commitment, could not. Moreover, failure of one party to fulfil its obligations did not entitle the other party to consider itself discharged of its obligations (that is, the inadimplendi non est adimplendum argument was not available to it). ${ }^{5}$ In later periods, devices were found to overcome such obstacles. For example, the entry into force of the first oath was delayed up to the moment of entry into force of the later oath; and the violation of the treaty was recognized as a cause of termination. ${ }^{6}$ The concept of a common legal order (international law), where treaties found their legal support, evolved only slowly. It came to full maturation only in the modern European period after Grotius. Enlightenment lawyers postulated pacta sunt servanda as the great overarching natural law principle for international relations. The way was thus cleared for treaties concluded exclusively under international law and having to be implemented through municipal law. In other words, municipal law was no longer the source of the treaty; it was

to reason that this will have to be done by agreements. There cannot be any customary law between us and them at the beginning of the contacts and for as long as a certain time has not elapsed.

4 For the old Near East treaties, see A. Altman, Tracing the Earliest Recorded Concepts of International Law, The Ancient Near East (2500-330 $B C E$ ) (Leiden/Boston, 2012), pp. 20ff, 34ff, 67ff, 111ff, 189ff; D. J. Bederman, International Law in Antiquity (Cambridge, 2001), pp.62ff, 137ff; R. Kolb, 'Short Reflections on the Basis of Obligation in Treaties of Ancient Cultures Pactum est servandum?', forthcoming.

5 Altman, op. cit., p. 72.

6 Ibid., pp. 117, 121. 
now limited to being a legal order relevant for determining the competence of conclusion and a legal order within which the treaty would possibly have to be implemented.

\section{Bilateral/Multilateral Treaties}

For a long time, treaties were exclusively bilateral in nature. Even seemingly multilateral compacts, such as the peace treaties in Westphalia in 1648, or the Vienna Peace Regulations of 1815, were indeed a complex bundle of bilateral treaties or commitments, each contracting party signing alternates with all other parties. Thus, a multilateral treaty between, say, four States, implied in fact and law the conclusion of six treaties or treaty relationships. This corresponds to the mathematic formula (n) multiplied with (n-1), divided by 2 . When the number of parties grows - as occurred in the 19th century - this procedure becomes very, if not excessively, cumbersome. $^{7} \mathrm{New}$ avenues of treaty conclusion are then sought. The multilateral treaty as a unique legal act ratified or acceded to by a number of States is a relatively modern invention. It has its roots in the 19th century. ${ }^{8}$ The first multilateral treaty was the Declaration of Paris on Maritime Warfare (1856), which ended the Crimean War (1853-1856). Some years later, this new procedure was applied to a more substantive treaty, namely the first Geneva Convention of 1864 for the Amelioration of the Conditions of the Wounded in Armies in the Field. ${ }^{9}$ Now, multilateral treaties are among the most important law-making conventions of the so-called international community, spanning any important subject matter. They touch on issues ranging from aviation to environmental issues, from financial and economic law to international organizations, from the settlement of disputes to outer space law, from protection of endangered species up to customs régimes. There are today roughly speaking 800 multilateral treaties of great importance in their respective subject matters. Many of them, that is, more than 500, are registered with the Secretary General of the UN. These are reported in the periodical publication, 'Multilateral Treaties Deposited with the Secretary General' (ST/LEG/SER.E/...). The recent coinage of the multilateral treaty shows the extent to which classical

7 If a universal multilateral treaty between 194 States would have, today, to be concluded in the old mode, this would necessitate 18,721 treaty relationships. Hardly a bright prospect.

8 K. Marek, 'Contribution à l'étude de l'histoire du traité multilatéral', in Essays in Honor of R. Bindschedler (Bern, 1980), p. $17 \mathrm{ff}$.

9 On these two conventions, see D. Schindler and J. Toman, The Laws of Armed Conflicts (Leiden/Boston, 2004), pp. 1055 and 365. 
international law was a law of bilateral adjustment and coexistence, not a law of international cooperation. It was centered on the State and not on any international society or even less, community. With the growth of common concerns in the 19th century a new multilateral treaty process became indispensable and established itself. It was used in particular for institutional arrangements, such as the Universal Postal Union.

\section{Reasons for the Importance of Treaties}

The reasons for the importance of treaties in the contemporary world are manifold. Some of the 'advantages' of treaties have to be seen in relation to alternative sources, in particular customary international law.

\section{Legal certainty}

The treaty guarantees in most cases a superior degree of stability and legal certainty to any other source of international law. The stability of treaties is a fundamental tenet of the law of treaties; it runs through the whole VCLT. The principle of the binding force of treaties is particularly well established (article 26 VCLT 1969). The violation of a treaty is traditionally beset with a high degree of odium - to wit, the scrap of paper doctrine, so vigorously condemned after World War II. The legal certainty of a subject matter significantly increases when the rules are laid down in writing and crafted with attention and care. It is almost impossible to set up detailed legal régimes - such as for the ban of chemical weapons - by unwritten rules. Thus, for example, if a detailed prisoners of war camp regulation needs to be adopted for the benefit of detained persons, this matter would hardly be left to customary law. Too many uncertainties would ensue, and with them different standards of treatment. This would run counter to some fundamental tenets of the law of armed conflict, namely the equality of belligerents under the law of war and the most effective guarantees for those protected persons. For this reason, the régime is set out in detail in Geneva Convention III of 1949. The same is true for international institutions. When an international organization or organ is to be set up, with all of its institutional arrangements, procedures, financing and the like, only written rules will suffice. Finally, the same can be said for the codification of international law itself. ${ }^{10}$ The law is codified by being put into writing, systematized

10 On the codification of international law, see for example, A. Watts, 'Codification and Progressive Development of International Law', in R. Wolfrum (ed.), The Max Planck Encyclopedia of Public International Law, Vol. II (Oxford, 2012), p. 282ff, with bibliographical references. 
and thus rendered accessible to the greatest number possible. When concluding a treaty on a certain subject matter, the States concerned thereby agree to extract that subject matter (for at least a certain time) from the chaotic flow of general political relations among them. They clothe it with a predictable legal régime, underpinned by a set of legitimate expectations as to mutual behaviour. When and how this choice is appropriate is a political matter. The States, as legislators, have to decide themselves on this issue, as they also have to decide when the time has come to give up this stability and to engage again in a greater flow and flux. The treaty will provide them with a legal instrument for achieving the degree of stability and certainty desired. It is thus no more than a tool of a multifaceted foreign policy.

\section{Flexibility}

International society is highly decentralized and complex. It groups States with the most diverse needs, cultures, outlooks and policies, and knows many levels of coexistence and cooperation, from the universal to the regional and down to the bilateral. It stands to reason that such a society needs a legal tool to provide for flexibility and adaptability. A single universal rule of customary law would be insufficient to cope with the many particular needs, in the same way that a domestic society knowing only the legislation and not the contract could not live up to the varying exigencies of private persons. The treaty allows for special legal régimes and relationships to be established among some States, thus departing from the general rules (or replacing them, when they do not exist) of international law. The treaty will in such cases prevail over the residual general rule under the legal principle that the more special law applies in priority to the more general one (lex specialis derogat legi generali; in toto jure, genus per speciem derogatur). Notice that the greater specialty must not refer to subject matter; it here refers to the number of States bound by the rule. Thus, there may be general rules on the flag State jurisdiction on the high seas, and a bilateral treaty on the same question, departing to some degree from the general rules. The latter would apply in the first place because it is reasonable to assume that the parties intended this: if they concluded such a bilateral treaty, it is because they wanted to depart from the general rule; had they not wished so, they would have maintained their legal relationships under the sway of the general rule. This mechanism of priority/derogation is limited only with regard to peremptory rules of the general law. They do not allow a more special rule between some parties to replace the general imperative injunction. This is the case in particular where fundamental common interests are at stake. 


\section{Participation}

Treaties have come to be greatly favoured as a source of international law by an important group of States, namely the so-called 'Third World' States or 'developing' States. From their viewpoint, the treaty is fundamentally a 'democratic' institution. In the multilateral conferences leading to its adoption, each State is represented on the basis of equality. True, the influence of a State will be a function of the quality of its personnel and its overall political weight. But even small States, by engaging some experts or by enjoying some prestige, can exert a significant influence over the negotiation and adoption process. In any event, each State is represented on an equal footing, possesses one vote when it comes to the adoption of the text and can freely make up its mind whether or not to ratify the text, possibly with or without reservations. The same cannot be said for customary international law, which the developing States initially mistrusted. Customary law does not provide as much equality. Weightier States, those with greater resources, better personnel, published practice, diplomatic influence, tend to have a greater share in the emergence of unwritten rules. Weaker States are at best in a position to protest some emerging rules and thus to impeach their establishment as customary rules. But even that supposes awareness and proper legal services. In brief, the multilateral treaty process approximates the democratic ideal of Parliamentarianism, with the direct participation of all States (or many States) in the making of the law. In an international society premised on sovereign equality (article 2, § 1, UN Charter) this is an asset. It is also an asset when the effectiveness of the law is considered, since participation in its making and adoption increases the chances that it will be taken seriously.

\section{Rapidity}

There is a series of questions which requires quick handling and timely legal regulation. Treaties can be adopted very quickly, especially on the bilateral level, according to the true needs of the States. Even multilateral procedures can be speeded up if the necessity is commonly felt and internalized. Moreover, a provisional application of treaty rules before their formal entry into force can be agreed to. It is more difficult to achieve a quick evolution of the law by the more cumbersome, uncertain and normally slower practice of States at the universal level. True, there are certain situations where a customary rule has developed quickly. Thus, the Montego Bay Convention on the Law of the Sea of 1982 provided for an exclusive economic zone (EEZ). ${ }^{11}$ Since coastal States

\footnotetext{
11 Article 55ff.
} 
were manifestly interested in extending their jurisdiction for economic matters up to 200 maritime miles from their low-water coastline, they quickly adopted legislation to that effect. Consequently, the International Court of Justice (ICJ) could hold in 1985 that the practice had already passed into customary international law. ${ }^{12}$ Conversely, the preparation of a treaty may take decades, as the ILC project on State responsibility shows. ${ }^{13}$ But the overall fact remains that treaties are concerted acts and can more easily be adopted in streamlined and short procedures than the growth of inorganic practice of States. The main alternative for a quickly adopted custom would be the 'instant custom' doctrine applied to some resolutions by the UN General Assembly (UNGA). But there remain too many legal uncertainties linked with that process.

\section{Reasons for the Importance of Customary International Law}

If those are the main advantages of treaties, what are, then, conversely, the main advantages of customary international law when compared with treaties? We may here mention the two most important ones.

First, customary law allows a higher degree of adaptability of the general rules of international law to evolving social needs at any given time. Treaty rules, once made, are difficult to change. Any change binding the same number of States as in the original treaty supposes in principle the consent of all the parties (but consent may be given in advance to accept a revision of a convention with less than unanimity and yet binding all the States parties ${ }^{14}$ ). Since international law is a law regulating political relationships between States (to the same extent that constitutional law regulates political relationships within States), and since political relationships shift much more - and much more quickly than private law relationships, there is a constant need to adapt the law and to keep it consonant to the needs and practice of the constituent unities of international society. This 'peaceful change' function, which is indispensable if the law is not to become partly outdated, irrelevant and unapplied, is essentially performed by customary international law. Notice that international law has no doctrine of the 'acte contraire'. This means that a treaty can be changed by subsequent treaty practice or by subsequent general practice, that is, by a customary law process (the

12 Continental Shelf case (Libya v Malta), ICJ Reports, 1985, p. 33, § 34.

13 See the summary description of the phases of work on that issue in S. Rosenne, 'The Perplexities of Modern International Law', RCADI, vol. 291, 2001, p. $382 \mathrm{ff}$.

14 See for example, article 108 of the UN Charter. 
reverse is also true). ${ }^{15}$ This state of affairs ensures the necessary mobility of the sources, avoiding their petrification.

Second, general customary international law, as distinguished from regional or bilateral customary rules, contains the only rules of international law which bind all the States of the world, and sometimes possibly also other entities than States. These addressees are bound even without an express consent, if only the practice and opinio juris is sufficiently general (which will mean that it is not opposed by a non-marginal number of States). In other words, treaty law produces in principle sets of 'particular international law' binding only those States which ratified or acceded; conversely, customary international law produces a series of rules of 'general international law' binding all States. This limited reach of conventional law is true even for important treaties, such as the UN Charter or the Geneva Conventions on international humanitarian law. Thus, the Eritrea/Ethiopia Arbitral Claims Commission had to establish in each of its awards that the substantive rules contained in the four Geneva Conventions of 1949 were also customary before it could apply them to the armed conflict between the two States (19982000), since Eritrea was not yet bound by these Conventions. ${ }^{16}$ There is no developed and complex society which could function only with the scattered and archipelagic sets of particular rules. It needs also some common law, that is, some general rules providing the societies with firm ground on which the idiosyncratic special régimes can be placed and managed so that the common bond is not entirely torn away.

\section{B DIGGING DEEPER}

\section{The Emergence of the Principle Pacta Sunt Servanda in European International Law}

In Roman Law - which exerted great influence on European legal thinking and practice ${ }^{17}$ - there was initially a rigid contractual formalism

15 W. Karl, Vertrag und spätere Praxis im Völkerrecht (Berlin, 1983); G. Nolte, Treaties and Subsequent Practice (Oxford, 2013).

16 See RIAA, vol. XXVI, for example, on p. $37 \mathrm{ff}$.

17 Roman Law was seen as the law of the Empire; when the Empire was resurrected in the Carolingian time, it seemed natural to inherit classical and Roman law as the law of the Empire. The surrounding ideological conception that old law was good law (principle of authority and tradition) was another pillar of this reception of Roman law. 
in the civil law (jus civile). ${ }^{18}$ The contracts clothed with legal protection were enumerated: contracts re, verbis (stipulatio), litteris and consensu. By contrast, contracts which did not fulfil the formal requirements of any of these categories were called nuda pacta or simply pacta. They were legally not protected: ex nudo pacto actio non oritur. ${ }^{19}$ It was, however, accepted that they could give rise to some procedural exceptions against the action of the other party. This civil law formalism has been progressively softened with the rise and strengthening of jus gentium. The latter concerned agreements concluded with non-Roman citizens, to which the Roman civil law was not held to be applicable. In this context, the Romans had recourse to the equitable idea that the simple promise given should be binding in good faith, without the necessity of any prescribed form. From here flowed the Roman principle of good faith and its consequence, pacta sunt servanda (a formula used by Cicero), in our context the fides publica inter populos. This significant advance of late Roman Law was partially lost with the demise of the Empire and the phase of the great migrations and invasions.

In the Middle Ages, it was taken up by the Church but combated by some influential jurists. The Christian faith is largely based on subjective ethics centered on motives and intentions (forum internum). ${ }^{20}$ Consequently, a promise must be considered sacred, all the more when God is invoked. In moral theology, the rule of respect for agreements was therefore postulated as a universal legal rule. ${ }^{21}$ Ecclesiastical jurisdiction

18 For details, see R. Kolb, La bonne foi en droit international public (Paris, 2000), p. $87 \mathrm{ff}$.

19 On these issues, see L. Seuffert, Zur Geschichte der obligatorischen Verträge (Nördlingen, 1881); W. Scherrer, Die geschichtliche Entwicklung des Prinzips der Vertragsfreiheit (Basle, 1948).

20 On the question of moral correction and the pledge by the word given, see Matthew, 5, 37.

21 H. Dilcher, 'Der Typenzwang im mittelalterlichen Vertragsrecht', Zeitschrift der Savigny-Stiftung für Rechtsgeschichte, Romanistische Abteilung, vol. 77, 1960, p. 272ff; E. Bussi, La formazione dei dogmi di diritto privato nel diritto comune, Vol. I (Padova, 1937), p. 217ff; J. Roussier, Le fondement de l'obligation contractuelle dans le droit classique de l'Eglise, Ph.D. (Paris, 1933); J. Bärmann, 'Pacta sunt servanda - Considérations sur l'histoire du droit consensuel', Revue internationale de droit comparé, vol. 13, 1961, p. 18ff; B. Schmidlin, 'Zum Gegensatz zwischen römischer und moderner Vertragsauffassung: Typengebundenheit und Gestaltungsfreiheit', in Essays in Commemoration of the Sixth Lustrum of the Institute for Legal History of the University of Utrecht (Assen, 1979), p. 111ff. See also K. P. Nanz, Die Entstehung des allgemeinen Vertragsbegriffs im 16. bis 18. Jahrhundert (Munich, 1985). 
contributed to give weight to this conception ${ }^{22}$ and ecclesiastical legislation gave ample room to the principle. ${ }^{23}$ Pacta sunt servanda had also as an advantage its simplicity - whereas the Roman formalism was complicated and obscure, and difficult to explain to the increasing number of subjects. From there, the principle was transferred into the developing common law (jus commune). ${ }^{24}$ However, a strong current of jurists faithful to the classical Roman conception as to the typologies of contracts and nuda pacta continued their polemic against the principle pacta sunt servanda. This was the case notably in France (mos gallicus). ${ }^{25}$ As can be seen, the question remained controversial.

The time to develop a 'modern' law of nations came after the demise of the Empire and the formation of a society of independent States, that is, progressively from the 17th century onwards, and in particular after the Westphalian Peace of 1648. It now stood to reason that an analogous application of the Roman civil law principles to international covenants could not be suitable. The kings and other rulers of the States were sovereign. They could not be forced to observe the forms of the old civil law; and the categories of contracts were hardly suitable for public treaties. Thus, the classical authors of international law, Grotius, ${ }^{26}$ Gentilii $^{27}$ or Vattel, ${ }^{28}$ and later Vitoria ${ }^{29}$ and Suarez, ${ }^{30}$ had been influenced

22 W. Trusen, 'Die gelehrte Gerichtsbarkeit der Kirche', in H. Coing (ed.), Handbuch der Quellen und Literatur der neueren europäischen Privatrechtsgeschichte, Vol. I (Munich, 1973), p. 467ff. See also H. Hattenhauer, Europäische Rechtsgeschichte (Heidelberg, 1992) pp. 315-16; J. Hashagen, 'Zur Charakteristik der geistlichen Gerichtsbarkeit vornehmlich im späten Mittelalter', Zeitschrift der Savigny-Stiftung für Rechtsgeschichte, Kanonistische Abteilung, vol. 37, 1916, p. $205 \mathrm{ff}$.

23. See for example, Decretum Gratiani, C.23, q. 1, c.3.

24 E. Bussi, La formazione dei dogmi di diritto privato nel diritto comune, Vol. I (Padova, 1937).

25 D. Liebs, Römisches Recht (2nd edn, Göttingen, 1982), p. 219. The French elegant jurists appertained to a philological school and were thus faithful to the classical sources. They feared that in giving up the nominal contracts, contract law would become amorphous. This has to be understood in the context of classical Roman Law, which was based on remedies (actiones); actions were conceded only for contracts having particular 'names', not for pacts at large which did not fit the system.

26 De jure belli ac pacis, Prolegomena, $\S 15$; Book I, Chap. $3, \S 16$; and most importantly Book II, Chap. 11. See also M. Diesselhorst, Die Lehre des Hugo Grotius vom Versprechen (Köln, 1959).

27 De jure belli, Book. I, Chap. 3.

28 Le droit des gens, Book I, Chap. 1.

29 Relectio de jure belli, Chap. 7. 
by the jus gentium-tradition and the Catholic authors, also by the law of the Church. From this tradition they could draw the rule pacta (nuda) sunt servanda. To the contrary, the civil law tradition was rather inhibitory. This fact also explains the mistrust of many of these authors, for example Grotius, as to civil law analogies in international law. ${ }^{31}$ The principle pacta sunt servanda now quickly became the cornerstone of the 'modern' international law. ${ }^{32}$ It is now intimately linked to the principle of sovereignty: if the rulers are sovereign, they cannot be bound by an international legal obligation unless they accept it (consensualism). But if international law as a whole is essentially based on agreements, then pacta becomes the founding principle for any legal obligation incurred in such a legal order, and it even becomes the basis of international law itself. ${ }^{33}$ In the wake of this development, the distinction between contractus and pactum was abandoned. By the same token, the Natural Law tradition which now held sway swept away the old formalism of Roman contracts and established the principle that most agreements between private persons could be concluded without any formal requirements. The word given, the pledge assumed, that is what truly counts in pure reason, not the observance of forms and rites, the invocation of obscure gods, the heritage of dark and ignorant ages. Thus, pacta sunt servanda eventually entered into some great continental codifications of private law, especially in Germany. Under the double progression of international and natural law, pacta sunt servanda became predominant in the law of treaties (international) and in the law of contracts (municipal).

The overall result is that a sweeping pacta sunt servanda principle emerges and establishes itself only in a particular socio-legal environment; it is not, as such, naturally necessary, however much it may seem so. It stands to reason that some form of binding compacts must be available in every society, lest any cooperation by agreements be rendered impossible. However, the exact way in which this capacity to bind

30 Defensio fidei, Book III, Chap. 5, 1, 2.

31 The issue is discussed in H. Lauterpacht, Private Law Sources and Analogies of International Law, London, 1927, p. 8ff. The issue is sometimes squarely addressed in the context of civil contracts and law of nations agreements: see for example, Gentili, De jure belli, Book I, Chap. 3.

32 G. S. Treuer, De auctoritate et fide gentium (Lipsia, 1747). H. Fagel, Dissertatione de foederum sanctitate (Leyde, 1785), Cap II, p. 23ff and Cap. IV, p. $59 \mathrm{ff}$.

33 This is the conclusion at which the mainstream positivist writers arrived: see for example, K. Strupp, 'Les règles générales du droit de la paix', RCADI, vol. 47, 1934-I, p. 301ff, in an ideally clear expression. 
oneself is conceded by a legal order is relative and contingent, that is, varying in time. A 'natural law' component (that there be a way to assume binding obligations) and a 'positive law' component (indicating the way for the assumption of binding obligations) are thus put into equilibrium.

\section{The Conclusion of Treaties in the Ancient Near East}

In ancient times law was part of a mythical rather than rational universe. It was linked to the divine order. Gods intervened directly in the affairs of the world. There was no dichotomy between the here and there as there exists in modern theological conceptions, particularly in the Christian tradition (sometimes at an extreme pitch as with Augustin's civitas terrena and civitas Dei). Law was seen and obeyed because it was part of a sacral order of the world. This explained that treaties between public collectivities were not binding by simple pledge or promise. The word had no value if it was not inserted into the complexion of the sacral order of things. Hence, pacta sunt servanda was not a general rule in such ancient societies. Rather, the compact was binding when it had been processed through the adequate formalistic rituals and the gods were addressed and taken as guarantors.

This state of affairs can be encountered in most ancient Near East Treaties of the Semitic peoples. During the Early Dynastic period of Southern Mesopotamia (2900 BCE), treaties were formal compacts: ritual acts, oaths, curses and invocation of Deities (each one in turn, so that the ritual is repeated many times) were predominant. ${ }^{34}$ The procedure remained unilateral since the parties undertook their obligations each one towards its own gods. Only then did they exchange their promises inscribed on tablets. ${ }^{35}$ The obligation was 'self-obligation'; but the unilateral effect was tempered by the participation of various national gods. The sanctity of the treaty rested not on a principle of rational nature, such as pacta sunt servanda; nor did it rest upon a common superior legal order, international law, which would have given force to such agreements. The basis of obligation was essentially seated in a unilateral promise which became binding by the oath and its surrounding formalism, and was then put under the guarantee of the gods. The gods would have to avenge violations of the agreement; the curse clauses are

34 A. Altman, Tracing the Earliest Recorded Concepts of International Law, The Ancient Near East (2500-330 BCE) (Leiden/Boston, 2012), p. $20 \mathrm{ff}$.

35 Ibid., p. 34ff. See also D. J. Bederman, International Law in Antiquity (Cambridge, 2001), p. 203. 
revealing in this regard. Notice also that since each oath and undertaking was a self-standing 'legal act', there was initially no room for reciprocity-arguments in the context of the treaty, notably based on some principle inadimplendi non est adimplendum. The violation of the promise by one party did not entitle the other to consider itself discharged of its own, independent, undertakings. ${ }^{36}$ This is understandable when one reflects on the fact that these obligations were assumed unilaterally and made binding by promises given to the parties' own gods. It was only progressively that sanctions to be taken by the parties themselves developed. Thus, in the Ancient Near East, we have to wait for the later Bronze Age (1600-1200 BCE), especially with the intense Hittite treaty practice, to find secular circumstances allowing the termination or suspension of a treaty. Three such circumstances were recognized in the Mesopotamian region at this time: ${ }^{37}$ (i) the violation of the treaty by the other party, with no distinction between minor of major breaches; (ii) the passing away of one king in the context of treaties intuitu personae; (iii) the removal from power of one of the parties, so that that party was no longer able to carry out its obligations (in modern terms: supervening impossibility of performance and fundamental change of circumstances).

The core of the matter were the oath (ritual) and the curse. The oath clauses invoked the Deities as guarantors of the treaty. ${ }^{38}$ The gods were extensively listed. The bond was undertaken in their name as much as in the name of the parties. They were also the witnesses of the bond. Such an oath clause could read as follows (take as an example a Hittite treaty): 'The Thousand Gods have now been called to assembly for [attesting the contents] of this treaty tablet that I have just executed for you. Let them see, hear, and be witness thereto, the sun-god of heaven, the sun-goddess of Arinna, the storm-god of heaven ...'39 This clause reflected the ritual of conclusion, with its invocation of gods, animal sacrifices and libations. The curse/blessing clauses were at least as important. They did not reflect the basis of obligation, which lay in the oath. Such clauses concerned the guarantee of the treaty and thus its application; they were a form of religious sanction for the treaty. ${ }^{40}$ As such, the curses are, however, closely linked to the basis of obligation. Such a curse clause could read as follows: 'If [treaty party] does not keep the words of the treaty and of

\footnotetext{
36 Altman, op. cit., p. 72.

37 Ibid., p. 121.

38 R. Lopez, 'Israelite Covenants in the Light of Ancient Near Eastern

Covenants', Chafer Theological Seminary Journal, no. 10, 2004, pp. 82-3.

39 Ibid., p. 82.

40 D. J. Bederman, International Law in Antiquity (Cambridge, 2001), p. 145.
} 
the oath, then let these oath gods destroy [treaty party] together with its head, his wife, his son, his grandson, his house, his city, his land ...' ${ }^{41}$ Or, as in the famous treaty of Alliance between Ramses II of Egypt and Hattusili King of the Hittites (1278 BCE): '[c]elui qui ne les respectera pas, que les mille dieux de Hatti et les mille dieux d'Egypte détruisent sa maison, son pays, ses serviteurs. Mais celui qui les respectera, que les mêmes dieux le maintiennent en prospérité et en vie, ainsi que ses biens et ses serviteurs. ${ }^{42}$ Hittites were often short on curses; conversely, Babylonians added elaborate lists of such curses. The content of the curses varied: ${ }^{43}$ for example contamination of drinking water; raising of evil winds; breaking the bow; clothing the body with leprosy; roaming the desert, the fields, and so on; bringing drought, flooding and famine; sickness; poison; infliction of injustice and darkness; and so on. The types of curses were also different: ${ }^{44}$ there were religious curses where gods were invoked to bring about a list of maledictions; there were 'simile' curses, where the fate of the law-breaker was described by an analogy ('Just as this figure is burned, so shall Aspad be burned if ...'); there were also simple maledictions where the oath-breaker was threatened with an evil fate, but no god was invoked ('May your days be dark, your years be dim'); there were, finally, 'futility' curses, where a desirable activity was first described and then its frustration was illustrated ('And you will eat, but not be satisfied'). In short terms, the treaty obligation was coagulated around the ritual - oath - and curse. Mere promises without the religious formulae were not held to be binding. ${ }^{45}$ The treaty obligation was thus assumed unilaterally in a process of self-obligation. The anarchical element of this treaty conclusion was tamed by the inclusion into the process of a transcendental third party, namely the gods. These were the 'guarantors' of the treaty: the obligation was assumed in their regard and thus had to be considered stable. Any violation of the treaty would be punished by the gods. The modern argument that a self-obligation cannot lead to a truly binding obligation since a subject that binds itself unilaterally can also unbind itself unilaterally - is not fully transferrable to this old treaty practice. The

41 R. Lopez, 'Israelite Covenants in the Light of Ancient Near Eastern Covenants', Chafer Theological Seminary Journal, no. 10, 2004, p. 85.

42 G. Contenau, La civilisation des hittites et des mitanniens, (Paris (Payot), 1934), p. 151.

43 See D. R. Hillers, Treaty-Curses and the Old Testament Prophets (Rome (Pontifical Biblical Institute), 1964), pp. 13-17.

44 Ibid, p. 12ff.

45 D. J. Bederman, International Law in Antiquity (Cambridge, 2001), p. 61. 
obligation was not entirely 'self', and in a certain sense was not at all 'self'. A powerful third party was designated as the ultimate source of the binding commitment. In turn, this binding oneself through a third-party was again tempered by the fact that the gods invoked were essentially 'national', that is, they were entrusted to protect the interests of the collectivity which they had founded and which they guarded. The treaty obligation obtained its ultimate reciprocal polish through the exchange of the unilateral undertakings: each one was done in view of the other; the tablets with the unilateral commitments were then exchanged; the text of the treaty was thus contained in two separate instruments; but the treaty had its core meaning in the conjunction of the two unilateral acts. 